\title{
Material Moving Workers
}

National Cancer Institute

\section{Source}

National Cancer Institute. Material Moving Workers. NCI Thesaurus. Code C122476.

The group of professions that include delivery truck drivers and driver/sales workers,

hand laborers and material movers, heavy and tractor-trailer truck drivers, and material moving machine operators. 